Prepared in cooperation with the Chelan County Public Utility District

\title{
Capture of White Sturgeon Larvae Downstream of The Dalles Dam, Columbia River, Oregon and Washington, 2012
}

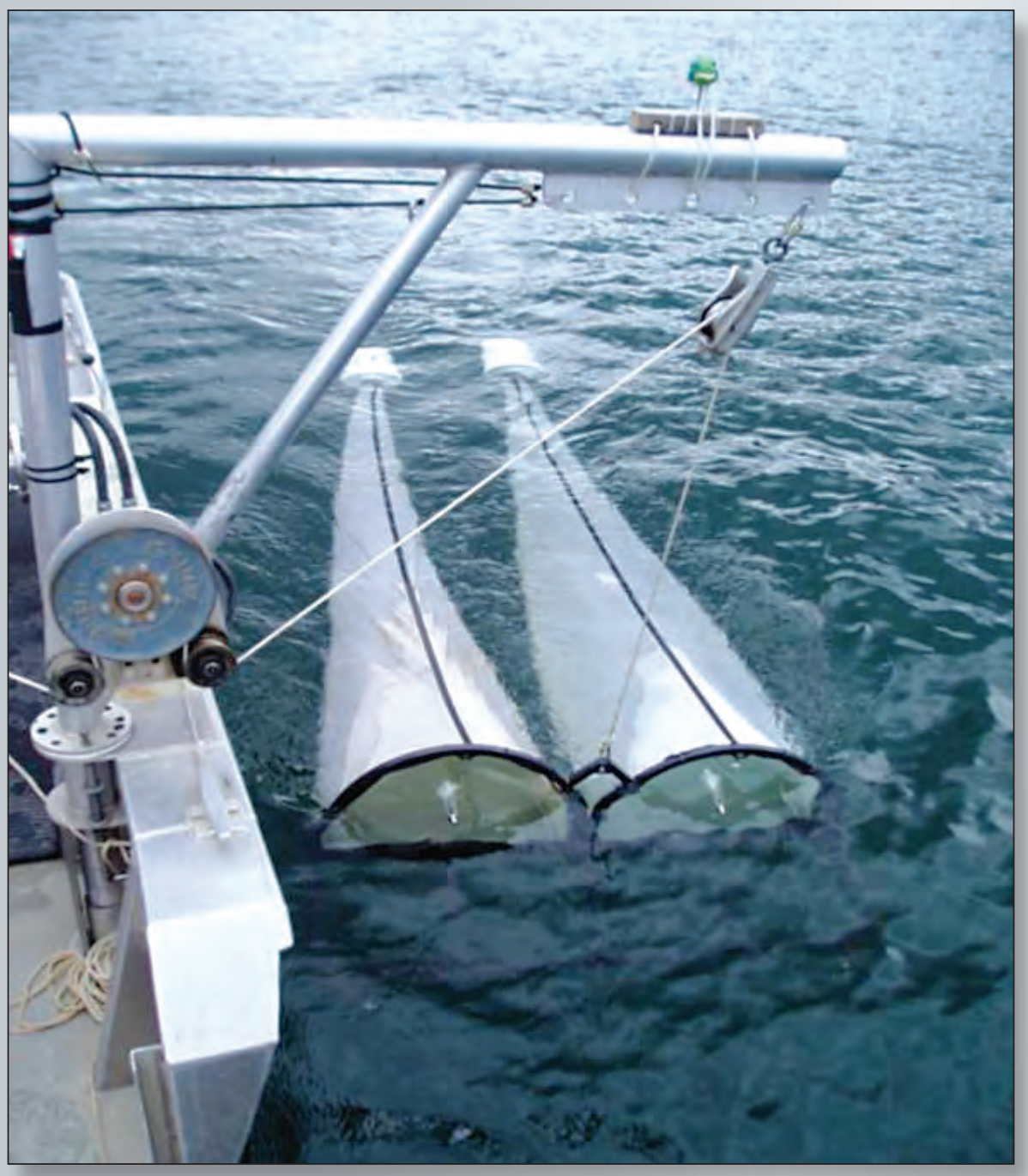

Open-File Report 2013-1110 
Cover: Photograph showing paired D-ring collection nets ready for deployment into the Columbia River in 2010. (Photograph by the Washington Department of Fish and Wildlife.) 


\section{Capture of White Sturgeon Larvae Downstream of The Dalles Dam, Columbia River, Oregon and Washington, 2012}

By Michael J. Parsley and Eric Kofoot

Prepared in cooperation with the Chelan County Public Utility District

Open-File Report 2013-1110

U.S. Department of the Interior

U.S. Geological Survey 


\title{
U.S. Department of the Interior \\ SALLY JEWELL, Secretary
}

\section{U.S. Geological Survey}

Suzette M. Kimball, Acting Director

\author{
U.S. Geological Survey, Reston, Virginia: 2013
}

For more information on the USGS-the Federal source for science about the Earth, its natural and living resources, natural hazards, and the environment-visit

http://www.usgs.gov or call 1-888-ASK-USGS

For an overview of USGS information products, including maps, imagery, and publications, visit $h$ ttp://www.usgs.gov/pubprod

To order this and other USGS information products, visit http://store.usgs.gov

Suggested citation:

Parsley, M.J., and Kofoot, E., 2013, Capture of white sturgeon larvae downstream of The Dalles Dam, Columbia River, Oregon and Washington, 2012: U.S. Geological Survey Open-File Report 2013-1110, 12 p.

Any use of trade, product, or firm names is for descriptive purposes only and does not imply endorsement by the U.S. Government.

Although this report is in the public domain, permission must be secured from the individual copyright owners to reproduce any copyrighted material contained within this report. 


\section{Contents}

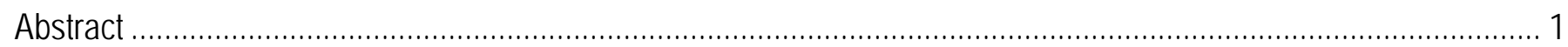

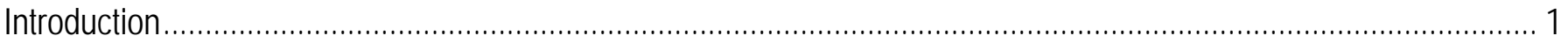

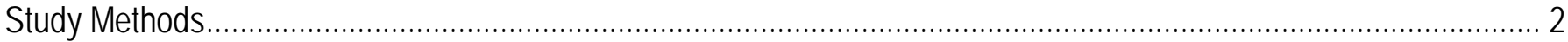

Site Selection and Capture of White Sturgeon in Early Life Stages.............................................................. 4

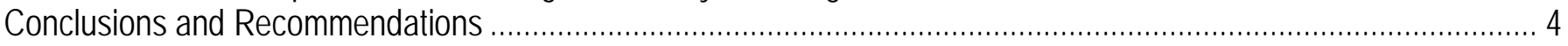

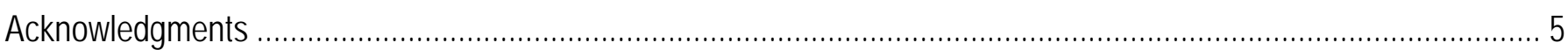

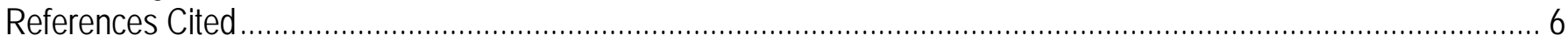

\section{Figures}

Figure 1. Image showing locations of netting sites A-E in the Columbia River downstream of The Dalles Dam ......... 7 Figure 2. Photograph showing paired D-ring nets ready for deployment in the Columbia River near Northport,

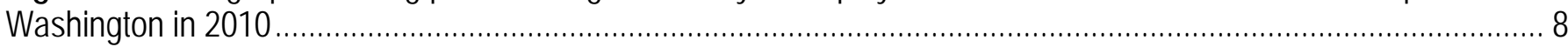

Figure 3. Photograph taken in 2012 showing a single D-ring frame with self-support base and net with 24.6 liter collection bucket attached to the end. 9

Figure 4. Graph showing Columbia River flow and water temperature for June at The Dalles Dam, 2012 .............. 9

Figure 5. Image of Columbia River study area showing white foam tracks as an indication of main river flow .......... 10

Figure 6. Image showing netting area with the wind-generated waves that are prevalent in this reach of the Columbia River

\section{Table}

Table 1. Capture data for white sturgeon early life stages (free-swimming embryos and larvae) downstream of The Dalles Dam, Oregon and Washington, June 25-29, 2012 


\section{Conversion Factors and Datum}

Conversion Factors

\begin{tabular}{lll}
\hline \multicolumn{1}{c}{ Multiply } & \multicolumn{1}{c}{ By } & To obtain \\
\hline kilometer $(\mathrm{km})$ & 0.6214 & mile (mi) \\
meter $(\mathrm{m})$ & 3.281 & foot $(\mathrm{ft})$ \\
centimeter $(\mathrm{cm})$ & 0.03937 & inch (in) \\
cubic foot $\left(\mathrm{ft}^{3}\right)$ & 0.02832 & cubic meter $\left(\mathrm{m}^{3}\right)$ \\
liter $(\mathrm{l})$ & 0.2462 & gallon \\
\hline
\end{tabular}

Temperature in degrees Celsius $\left({ }^{\circ} \mathrm{C}\right)$ may be converted to degrees Fahrenheit $\left({ }^{\circ} \mathrm{F}\right)$ as follows:

${ }^{\circ} \mathrm{F}=\left(1.8 \mathrm{x}^{\circ} \mathrm{C}\right)+32$

Datum

Horizontal coordinate information is referenced to the World Geodetic System (WGS-84) 


\title{
Capture of White Sturgeon Larvae Downstream of The Dalles Dam, Columbia River, Oregon and Washington, 2012
}

\author{
By Michael J. Parsley and Eric Kofoot
}

\begin{abstract}
Wild-spawned white sturgeon (Acipenser transmontanus) larvae captured and reared in aquaculture facilities and subsequently released, are increasingly being used in sturgeon restoration programs in the Columbia River Basin. A reconnaissance study was conducted to determine where to deploy nets to capture white sturgeon larvae downstream of a known white sturgeon spawning area. As a result of the study, 103 white sturgeon larvae and 5 newly hatched free-swimming embryos were captured at 3 of 5 reconnaissance netting sites. The netting, conducted downstream of The Dalles Dam on the Columbia River during June 25-29, 2012, provided information for potentially implementing full-scale collection efforts of large numbers of larvae for rearing in aquaculture facilities and for subsequent release at a larger size in white sturgeon restoration programs.
\end{abstract}

\section{Introduction}

The purpose of this study was to investigate the feasibility of capturing wildspawned white sturgeon larvae from the Columbia River downstream of The Dalles Dam in numbers sufficient to be removed to aquaculture facilities for subsequent rearing and release. The Washington Department of Fish and Wildlife has successfully netted white sturgeon larvae from the Columbia River near Northport, Washington, reared the larvae for several months in their Sherman Creek Hatchery, and subsequently released several thousand juvenile white sturgeon into Lake Roosevelt, an impoundment on the Columbia River (Washington Department of Fish and Wildlife, unpub. data, 2010, 2011). Sturgeon populations are declining in many areas of the Columbia River that are impounded by dams (Miller and others, 1995) and capture, rearing, and subsequent release of young wild-spawned white sturgeon is one alternative for restoring abundance in areas where natural production is low or non-existent. Capture of larvae presents an alternative to traditional approaches of wild broodstock capture, transportation, and spawning within an aquaculture facility. Capture of broodstock can be labor intensive or impractical because of low capture probability in areas where adult fish numbers are low. The transportation of mature fish, which typically exceed $1.5 \mathrm{~m}$ in length, to and from an aquaculture facility 
for spawning and return to the river requires specialized trucks and procedures. In contrast, white sturgeon larvae typically can be captured each year downstream of most known spawning areas. Larvae can be transported to hatcheries in standard coolers, and a subsequent return trip to release broodstock is not necessary.

Chelan County Public Utility District (PUD) requested that the U.S. Geological Survey (USGS) conduct a feasibility study to determine if capturing wild-spawned sturgeon larvae can be a viable alternative to hatchery production for meeting their Federal Energy Regulatory Commission licensing conditions. This study was conducted in response to this request. We considered this to be a reconnaissance study because there was uncertainty regarding potential netting sites, how debris would affect net performance, and how many larvae would be captured per unit of time. This information will be used to estimate sampling efforts for future collection activities. The USGS has captured white sturgeon in early life stages from the Columbia River downstream of The Dalles Dam in previous studies (Parsley and others, 1993; U.S. Geological Survey, unpub. data, 1995, 1998), but it was not the goal of those studies to maximize catches of sturgeon during their larval dispersal phase. Thus, the objective of this pilot study was to identify potential sites suitable for long-term deployment of nets that did not interfere with commercial navigation or Tribal fishing activities, and determine how long the nets could be fished before the amount of debris became too great to effectively fish or resulted in mortality of white sturgeon in early life stages. The potential study reach extended from the Highway 197 Bridge (river km 308) downstream approximately $11 \mathrm{~km}$ (fig. 1).

The study was conducted by the USGS in cooperation with the Chelan County PUD. The work directly addressed several aspects of the USGS Science Strategy (U.S. Geological Survey, 2007). Understanding the conservation requirements and opportunities for restoration of fisheries in a large, managed inter-jurisdictional river is relevant to the "Understanding Ecosystems and Predicting Ecosystem Change" strategic direction. Working with the Chelan County PUD and others to restore fisheries is a critical step toward informed river management. This study also supported several of the goals and objectives of the Fisheries-Aquatic and Endangered Resources Program within the Ecosystems Mission Area. This work will assist with evaluations of the effectiveness of management plans to recover imperiled aquatic organisms, as it will assist with the development of restoration and reestablishment techniques for white sturgeon, and it provides timely, responsive, and cost-effective information in response to issue-driven, site-specific management problems involving targeted short-term research.

\section{Study Methods}

Drift-fishing plankton nets deployed on the riverbed have long been used to collect early life stages of white sturgeon in the Columbia River and elsewhere (Parsley and others, 1993; McCabe and Tracy, 1994). The Washington Department of Fish and Wildlife recently refined techniques for long-term (for example, overnight) netting by incorporating a large collection bucket, a self-standing base, and a mooring system that enables retrieval and redeployment of the net (figs. 2 and 3). A netting effort consisted of single or paired deployments of inverted U-shaped plankton nets, commonly referred to 
as D-ring nets, which are weighted and fished on the riverbed. The nets are deployed on moorings to collect sturgeon in early life stages (eggs, free-swimming embryos, and larvae) downstream of spawning sites. The nets are fitted with a large collection bucket specifically designed to minimize harm to fish that are collected.

Specifically, the individual net frame openings measured $0.8-\mathrm{m}$ wide by $0.6-\mathrm{m}$ high. The frames were welded to a rectangular base constructed of 2.54-cm steel square tubing that allows the nets to stand upright on the river bottom. The nets, made of 1.6mm knotless nylon mesh (Delta weave), were $3.4 \mathrm{~m}$ in length and had a mouth diameter of $68.58 \mathrm{~cm}$ and a cod opening of $10.16 \mathrm{~cm}$. A 24.6-L collection bucket was attached to the cod end of the net. The collection buckets were modified by cutting five columns of 3.18-cm-diameter holes (4 holes per column) covered with $750-\mu \mathrm{m}$ Nitex ${ }^{\circledR}$ mesh screen. A 10.16-cm-diameter hole was cut in the center of the bucket lid and two 10.1-cm closet flanges were placed back-to-back on either side and attached with bolts. A 15.24-cmdiameter ABS pipe glued into the outer flange was used for net attachment. Ground gear consisted of a Y-bridle fastened to the frame base with a line leading to a 45-kg fluke anchor. A vertical line with floats was tied to the top of the frame and extended to the water surface for deploying and retrieving the nets. Line lengths varied depending on depth.

Net deployment sites were determined from prior knowledge of capture locations of white sturgeon in early life stages (Parsley and others, 1993) and by examining physical river structure including substrates, bathymetry, and hydrodynamic model output for suitable depths and water velocities. Onsite evaluation and assessment of proximity to the federally maintained navigation channel, Native American traditional fishing locations, and prevailing wind and surface-wave conditions ultimately determined whether a site could be fished with nets.

Once suitable sites were identified, the nets were deployed and left to fish for 8 or more hours. Geographic coordinates from a global positioning system receiver were recorded at all netting sites along with the date and time of net deployment, and retrieval and water depth. Upon retrieval, the contents of the collection bucket were emptied into a sorting tray and captured white sturgeon were counted.

The schedule for the field work was based primarily on ambient Columbia River water temperatures. Spawning by sturgeon in The Dalles Dam vicinity typically begins when water temperatures reach $12^{\circ} \mathrm{C}$, and peaks when water temperatures reach 14$15^{\circ} \mathrm{C}$. Given that targeted fish would be approximately 12 days of age, which is the age at which downstream dispersal typically occurs, collection efforts were set to begin when water temperatures had been equal to or greater than $15^{\circ} \mathrm{C}$ for at least 6 days (fig. 4). 


\section{Site Selection and Capture of White Sturgeon in Early Life Stages}

Columbia River flows were exceptionally high during June 25-29, 2012, when the netting efforts occurred (fig. 4). Netting efforts were conducted adjacent to the thalweg and navigation channel to avoid high water velocities that prevailed during the high flows. Water depths at netting sites ranged from 16.8 to $32.0 \mathrm{~m}$. Sturgeon catches were highest in the three sites farthest downstream (sites C, D, and E) with a total of 103 larvae and 4 free-swimming embryos (table 1). The highest overall sturgeon catch was 86 larvae at site D. Netting at sites A and B resulted in the capture of only one sturgeon freeswimming embryo. Netting resulted in the immediate mortality of four larvae. All other larvae appeared to be in good condition and were observed swimming within the sorting trays, suggesting that they would have been suitable for transport to a rearing facility. The amount of debris that accumulated in the collection bucket varied within and among sites, with a median of 25 percent of the bucket by volume (range 0-100 percent).

\section{Conclusions and Recommendations}

The work involved with this study demonstrated that there is potential to capture white sturgeon in early life stages that could be transported to rearing facilities for use in restoration or population supplementation elsewhere in the Columbia River. The 1-weeklong effort presented in this report was exploratory in nature and provided information on where future collection efforts should be focused. It is common in developing fisheries to see rapid increases in catch-per-unit effort as fishers gain knowledge of fishing grounds and experience in capturing target species or, in this case, a specific age class of a single species. The long duration of the spawning period and short incubation of white sturgeon eggs would ensure that early life stages of white sturgeon would be present for several weeks or months in each year, thus enabling the development of a netting program that could address concerns about inbreeding or outbreeding depression that arise in aquaculture-based fish restoration programs.

The Columbia River downstream of The Dalles Dam was a challenging environment because the selection of suitable netting sites that could be fished for extended periods had to consider river channel morphometry, commercial navigation, Native American fishing locations, and recreational anglers. The availability of suitable locations was further constrained by factors influencing crew safety including appropriate current velocity and wind generated waves. Netting sites ultimately selected for this study came from careful consideration of each of these factors as well as information from previous studies in which white sturgeon larvae were captured. Previous catch data revealed that white sturgeon larvae can be captured from downstream locations where the river channel widens and water velocities are reduced. However, wind-generated waves can become problematic on some days in this area (fig. 5). Netting closer to the thalweg here and at sites farther upstream or downstream may be possible during lower water years with reduced river discharge during the larvae dispersal period. 
Future netting efforts to provide greater numbers of white sturgeon larvae sufficient to transport to hatcheries for rearing should use a vessel with the following features:

- An open bow design of adequate length for work in high waves generated by prevailing high winds that are common in the Columbia River Gorge (fig. 6). In this study, wind-generated waves made work difficult or precluded lifting some of the nets on some days in the 7-m-long vessel used. A vessel with an open bow design would allow easy access to the anchor pulpit and windlass, thus improve crew efficiency.

- Fairleads or vertical rollers on the anchor pulpit to keep the anchor line on the pulpit roller during net lifting or anchor retrieval.

- The davit used for lifting nets mounted forward of amidships for improved safety.

- An anchor windlass or capstan adequate to lift the 45-kg anchors and rode. Drag from the water current on the long anchor rode required at the deep sites required substantial power to lift and retrieve anchors.

\section{Acknowledgments}

Jason McLellan and Matt Howell, formerly from the Washington Department of Fish and Wildlife, and currently with the Confederated Tribes of the Colville Reservation, developed modifications to traditional D-ring nets and deployment methods that were used in this study. We thank them for sharing their thoughts and designs. This study was funded by the Chelan County Public Utility District, for which Joshua Murauskas was the technical point of contact. Nets, moorings, and ground gear used in this study were provided by Chelan County PUD. Assistance with the field work was provided by Dave Beardsley, Dennis Litchfield, Nate Clark, Chris Vanwey, and Ed Gutzwiler of the Chelan County Public Utility District. Joe Warren of the U.S. Geological Survey provided assistance with figures, tables, and the formatting of this report. Sturgeon netting efforts were authorized under Washington State Scientific Collection Permit 12-190, and Oregon Department of Fish and Wildlife Scientific Taking Permit Number 17251. 


\section{References Cited}

McCabe, G.T., Jr., and Tracy, C.A., 1994, Spawning and early life history of white sturgeon, Acipenser transmontanus, in the lower Columbia River: Fishery Bulletin, v. 92, p. 760-772.

Miller, A.I., Counihan, T.D., Parsley, M.J., and Beckman, L.G., 1995, Columbia River Basin white sturgeon, in LaRoe, E.T., ed., Our living resources-A report to the nation on the distribution, abundance, and health of U.S. plants, animals, and ecosystems: U.S. Department of the Interior, National Biological Service, Washington, D.C., p. 154-158.

Parsley, M.J., Beckman, L.G., and McCabe, G.T., Jr., 1993, Spawning and rearing habitat use by white sturgeons in the Columbia River downstream from McNary Dam: Transactions of the American Fisheries Society, v. 122, p. 217-227.

U.S. Geological Survey, 2007, Facing tomorrow's challenges-U.S. Geological Survey science in the decade 2007-2017: U.S. Geological Survey Circular 1309, 70 p. 


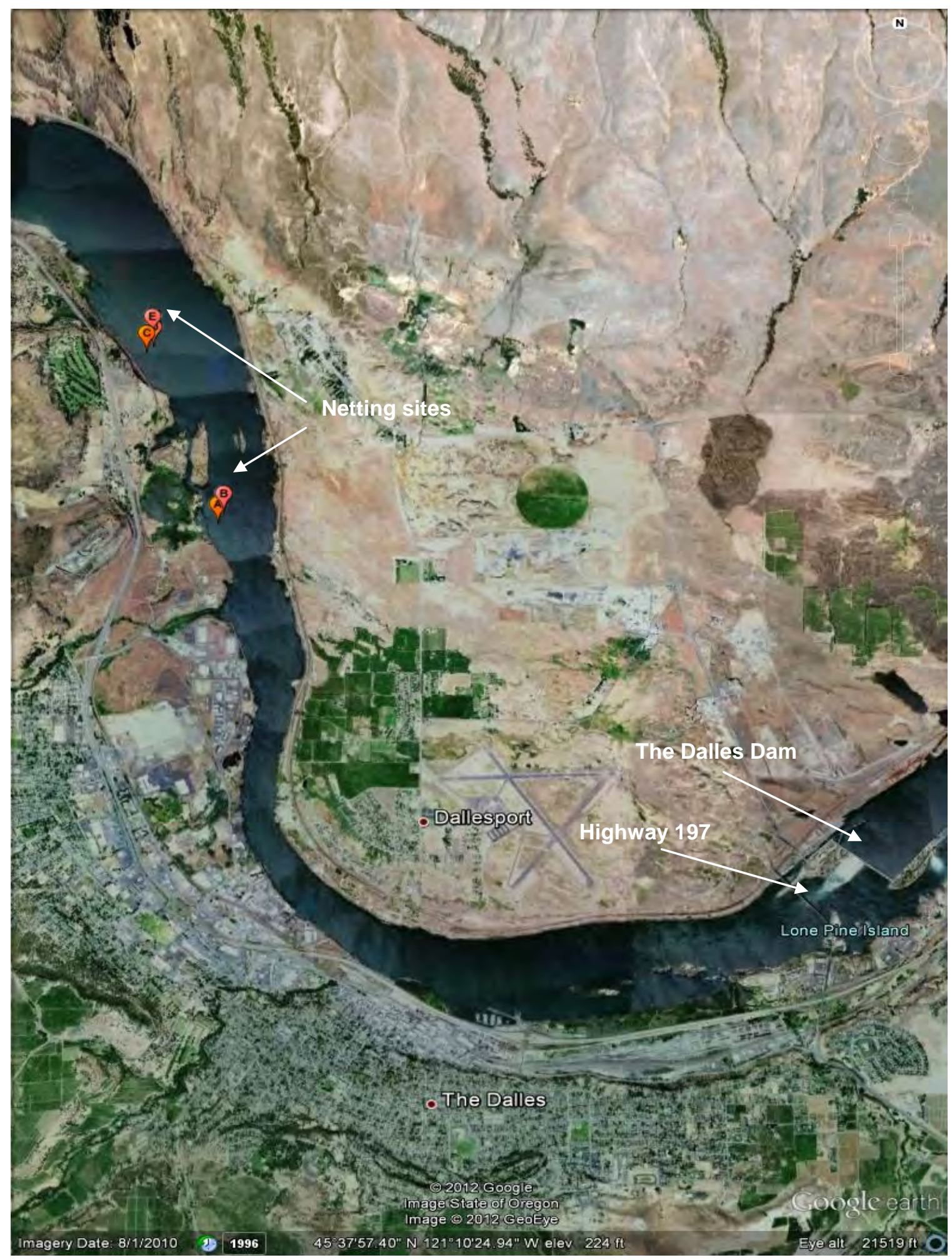

Figure 1. Image showing locations of netting sites A-E in the Columbia River downstream of The Dalles Dam. River flow is from east to west. 


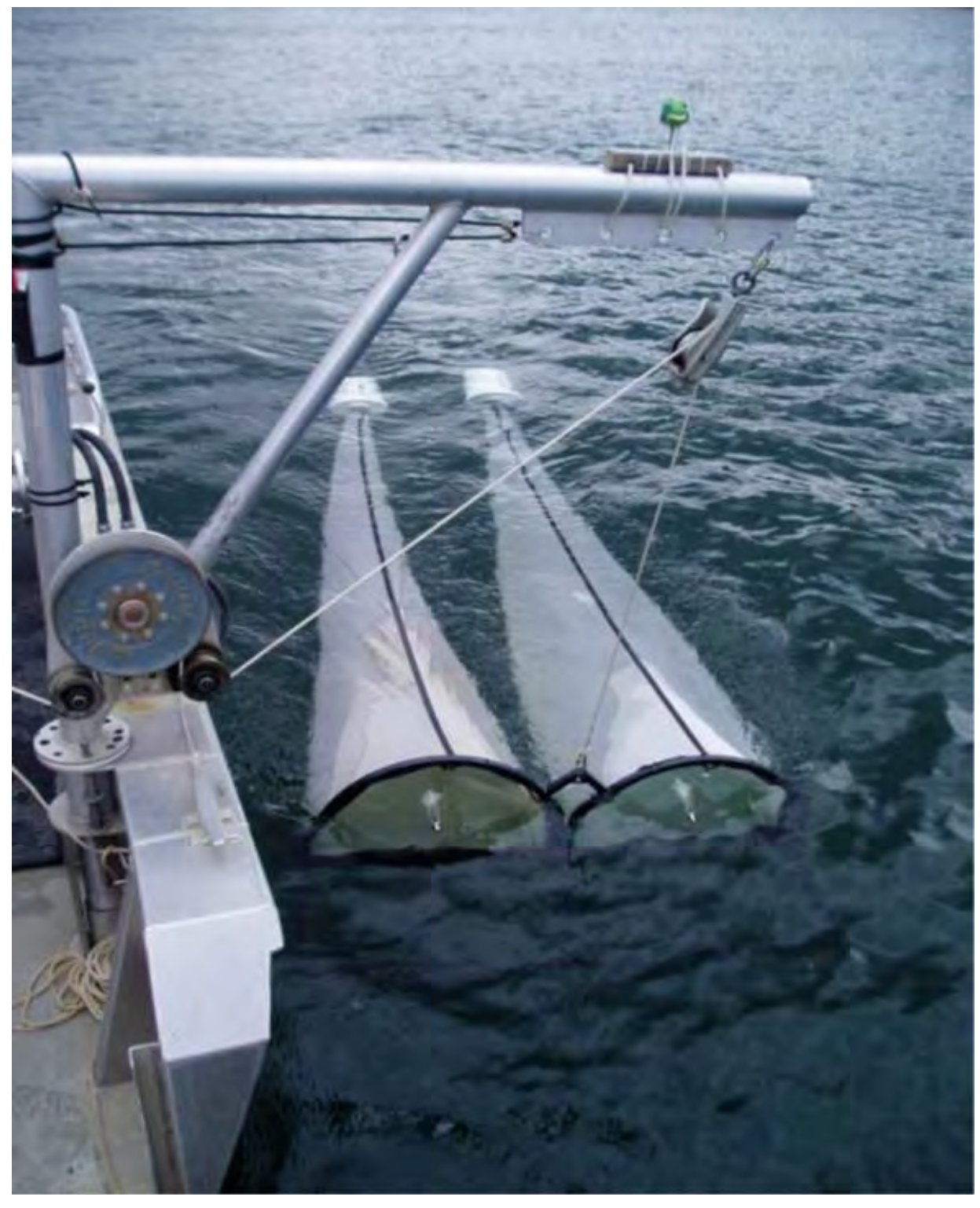

Figure 2. Photograph showing paired D-ring nets ready for deployment in the Columbia River near Northport, Washington in 2010. Photograph courtesy of Washington Department of Fish and Wildlife. 


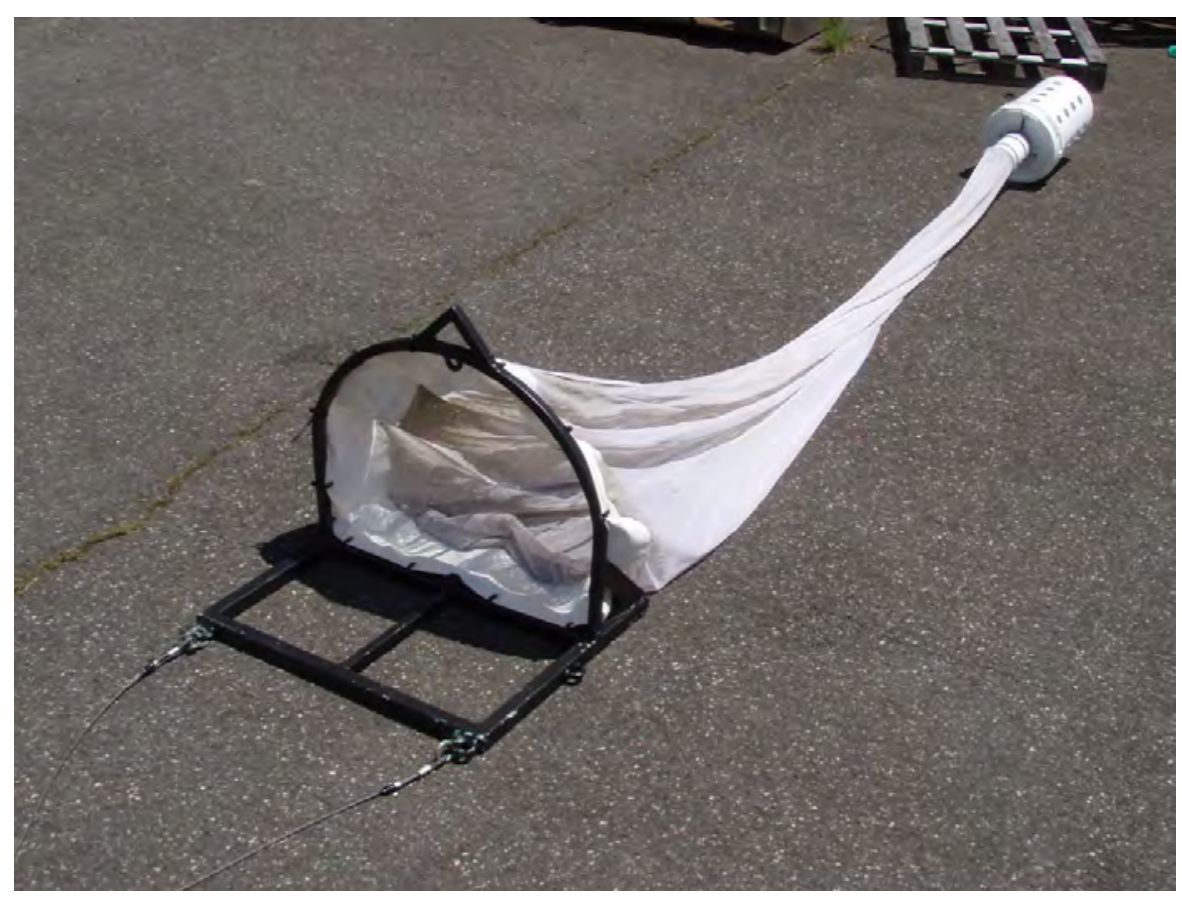

Figure 3. Photograph taken in 2012 showing a single D-ring frame with self-support base and net with 24.6 liter collection bucket attached to the end. A surface float for net retrieval would be attached to the loop at the top of the net frame.

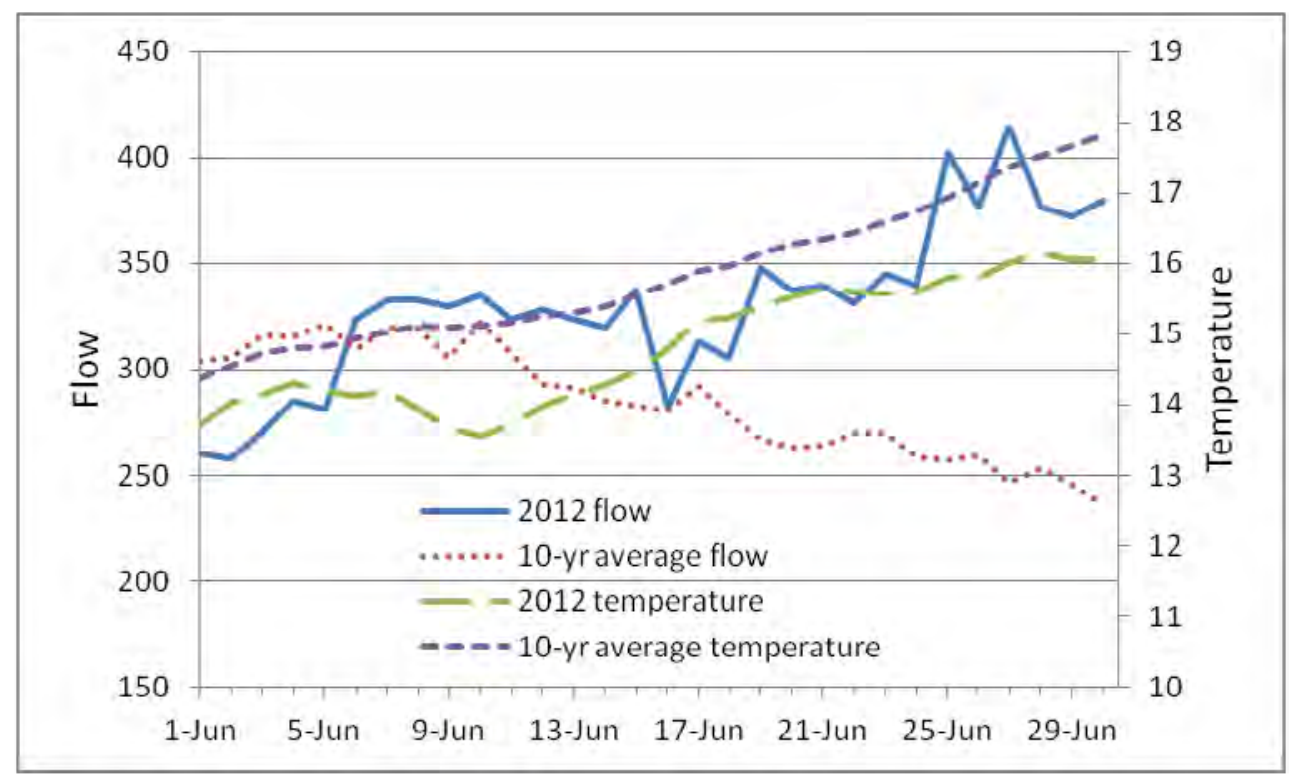

Figure 4. Graph showing Columbia River flow and water temperature for June at The Dalles Dam, 2012. Flows in 2012 were much higher than the 10-year averages, and water temperatures were colder in 2012 than the 10-year averages. 


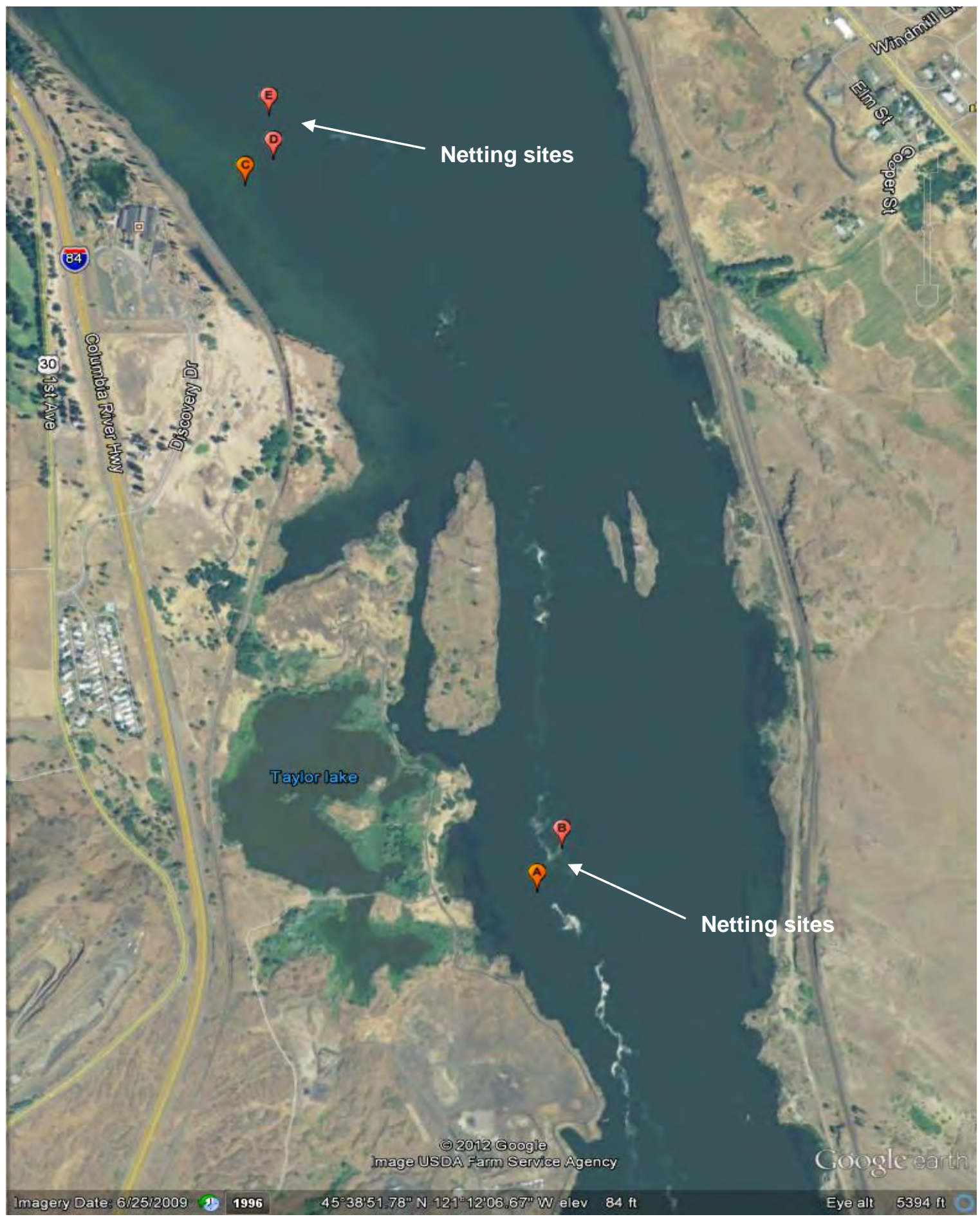

Figure 5. Image of Columbia River study area showing white foam tracks as an indication of main river flow. 


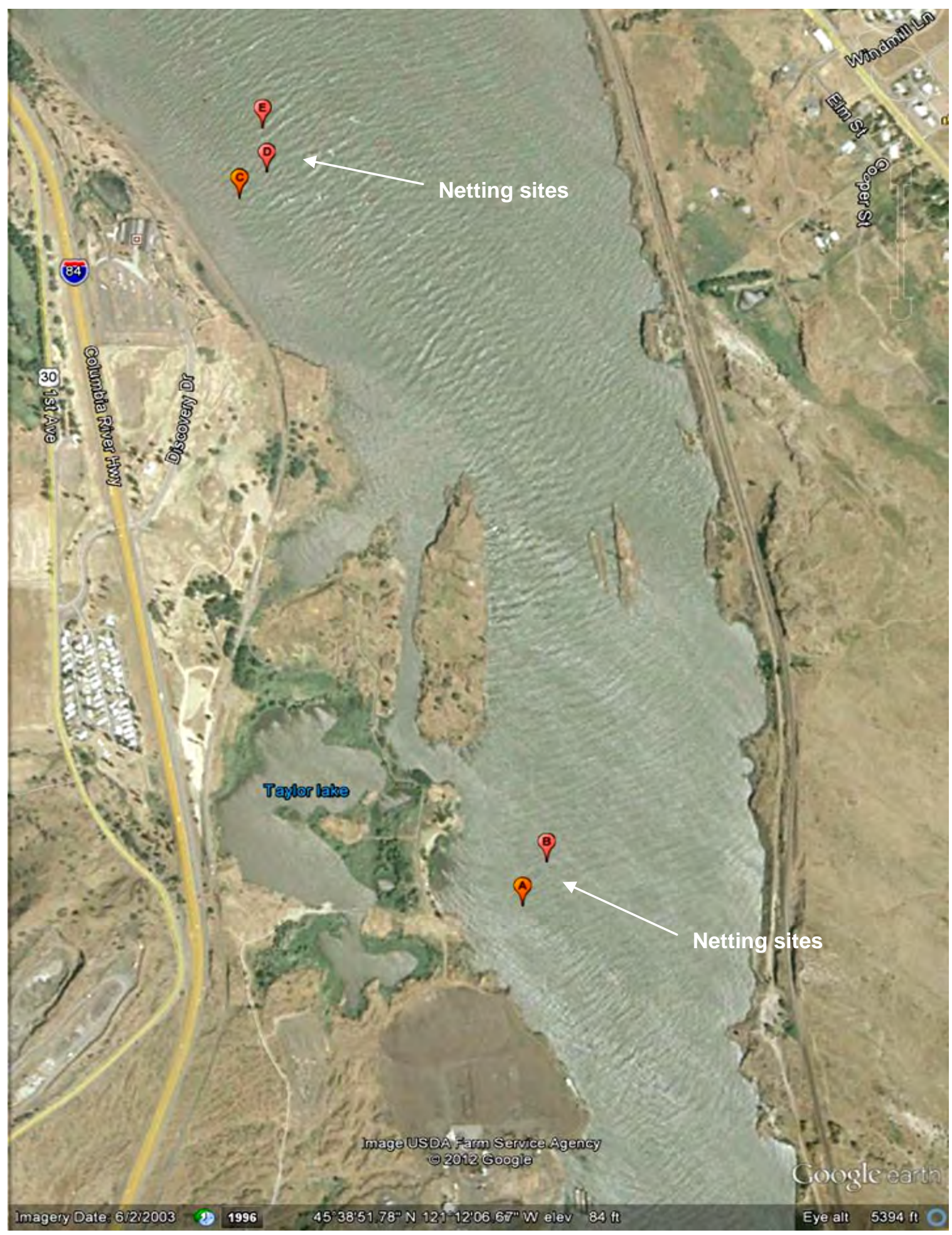

Figure 6. Image showing netting area with the wind-generated waves that are prevalent in this reach of the Columbia River. River flow is from south to north. Wind direction is northwest to southeast. 
Table 1. Capture data for white sturgeon early life stages (free-swimming embryos and larvae) downstream of The Dalles Dam, Oregon and Washington, June 25-29, 2012.

[Set numbers refer to consecutive efforts at each site. Site D was fished with a paired net; all other sites were fished with a single net. Debris was then estimated as the fractional volume in the collection bucket]

\begin{tabular}{|c|c|c|c|c|c|c|c|c|c|c|}
\hline Site & Latitude & Longitude & $\begin{array}{c}\text { Depth } \\
\text { (m) }\end{array}$ & Set & $\begin{array}{l}\text { Duration } \\
\text { (hr) }\end{array}$ & $\begin{array}{l}\text { Volume } \\
\text { of debris } \\
\text { (percent) }\end{array}$ & $\begin{array}{l}\text { Number of } \\
\text { sturgeon free- } \\
\text { swimming } \\
\text { embryos }\end{array}$ & $\begin{array}{l}\text { Number of } \\
\text { sturgeon } \\
\text { larvae }\end{array}$ & $\begin{array}{l}\text { Number of } \\
\text { dead } \\
\text { sturgeon } \\
\text { larvae }\end{array}$ & $\begin{array}{l}\text { Catch } \\
\text { per } \\
\text { hour }\end{array}$ \\
\hline \multirow[t]{3}{*}{ A } & $453829.3 N$ & $1211202.8 \mathrm{~W}$ & 32 & 1 & 22.08 & 6.25 & 0 & 0 & 0 & 0.00 \\
\hline & & & & 2 & 25.18 & 25 & 0 & 0 & 0 & 0.00 \\
\hline & & & & 3 & 26.25 & 0 & 1 & 0 & 0 & 0.04 \\
\hline \multirow[t]{3}{*}{ B } & $453832.4 \mathrm{~N}$ & $1211200.6 \mathrm{~W}$ & 29.6 & 1 & 17.52 & 6.25 & 0 & 0 & 0 & 0.00 \\
\hline & & & & 2 & 24.58 & 33 & 0 & 0 & 0 & 0.00 \\
\hline & & & & 3 & 25.25 & 0 & 0 & 0 & 0 & 0.00 \\
\hline \multirow[t]{4}{*}{$\mathrm{C}$} & $453919.0 \mathrm{~N}$ & 12112 28.8W & 16.8 & 1 & 14.33 & 20 & 0 & 0 & 0 & 0.00 \\
\hline & & & & 2 & 24.42 & 33 & 0 & 2 & 1 & 0.08 \\
\hline & & & & 3 & 8.83 & 33 & 0 & 0 & 0 & 0.00 \\
\hline & & & & 4 & 11.42 & 12.5 & 4 & 1 & 0 & 0.44 \\
\hline \multirow[t]{4}{*}{$\mathrm{D}$} & $453920.8 \mathrm{~N}$ & 12112 26.3W & 21.3 & 1 & 23.47 & 5 & 0 & 0 & 0 & 0.00 \\
\hline & & & & 2 & 24.08 & 100 & 0 & 2 & 0 & 0.08 \\
\hline & & & & 3 & 9.83 & 50 & 0 & 32 & 0 & 3.26 \\
\hline & & & & 4 & 13.67 & 25 & 0 & 52 & 3 & 3.80 \\
\hline \multirow[t]{3}{*}{$\mathrm{E}$} & $453923.9 \mathrm{~N}$ & $1211226.7 \mathrm{~W}$ & 19.8 & 1 & 21.25 & 50 & 0 & 0 & 0 & 0.00 \\
\hline & & & & 2 & 11.42 & 33 & 0 & 10 & 0 & 0.33 \\
\hline & & & & 3 & 12.12 & 12.5 & 0 & 4 & 0 & 0.00 \\
\hline
\end{tabular}


Publishing support provided by the U.S. Geological Survey

Publishing Network, Tacoma Publishing Service Center

For more information concerning the research in this report, contact the Director, Western Fisheries Research Center

U.S. Geological Survey

6505 NE 65th Street

Seattle, WA 98115

http://wfrc.usgs.gov/ 
